\title{
Evaluating Estimates of Materials Offshoring from U.S. Manufacturing*
}

by

\author{
Robert C. Feenstra \\ University of California, Davis and NBER \\ J. Bradford Jensen \\ Georgetown University and NBER
}

October 2009

\footnotetext{
* The authors thank Greg Wright, UC Davis, who prepared portions of this paper and JoséDaniel Reyes, Georgetown, for research assistance. We thank Belinda Bonds of the Goods and Distributive Services Branch at the Bureau of Economic Analysis for assistance. Some of the analysis in this paper was conducted at the Center for Economic Studies, U.S. Census Bureau. The results have not undergone the review accorded Census Bureau publications and no endorsement should be inferred. Any opinions and conclusions expressed herein are those of the author(s) and do not necessarily represent the views of the U.S. Census Bureau or the NBER. All results have been reviewed to ensure that no confidential information is disclosed.
} 


\section{Introduction}

When materials offshoring is measured by estimating imported intermediate inputs, a common assumption used is that an industry's imports of each input, relative to its total demand, is the same as the economy-wide imports relative to total demand: this is the so-called "import comparability assumption” (Houseman, 2008, p. 9), or the “proportionality assumption ” (OECD STAN database). That assumption was made by Feenstra and Hanson (1999), for example, and was critiqued by the National Research Council report (NRC, 2006) as being a significant limitation of current data collection and analysis. Recent work by Winkler and Milberg (2009) for Germany shows that this assumption does not hold up well when compared to the actual imports by industries. For the United States, too, it is highly desirable to move beyond this assumption to obtain a direct measure of imported materials by industry.

The goal of this project is to obtain such an industry-level measure of offshoring for the U.S. We begin, however, with a smaller first step. In the first step, we explore alternatives to the Feenstra-Hanson (1999) measure of offshoring that still make use of the import comparability assumption. While that measure of offshoring was intended to reflect imported intermediate inputs, in practice it also included imported final goods. So in this first step, we re-calculate the Feenstra-Hanson (1999) measure of offshoring while focusing on only imported intermediate inputs as defined by end-use classifications. This approach has been taken by several other recent authors, including Wright (2009), Sitchinava (2007, 2008) and Bergstrand and Egger (2008).

In the second step, we explore a different methodology for allocating imported inputs across industries using firm level data on imports and production. We use information on imports from the Linked/Longitudinal Firm Trade Transaction Database (LFTTD), which links individual U.S. trade transactions to firms and information on materials used and products 
produced from the Census of Manufactures. We use the linked production and import data to construct firm-level input-output tables and then aggregate these to the industry level to derive imported input intensity by industry and compare our results with those obtained by the BEA using the "import comparability" assumption. Our focus is on imports of intermediate inputs, so we exclude from the analysis products identified at “final goods” by Wright (2009). We confront a number of technical and data issues and make several compromises as a result, all of which we describe in the paper. We describe differences between the import matrix constructed using firm level import data and BEA’s import matrix.

\section{The Import Comparability Assumption}

Our goal is to update the offshoring measure described in Feenstra and Hanson (1996, 1999) which is defined for any industry k purchasing inputs $\mathrm{j}$ as:

Industry k share of intermediate inputs that are imported

$$
=\frac{\sum_{j}(\text { industry k purchases of good } \mathrm{j})\left(\frac{\text { imports of good } \mathrm{j}}{\text { total domestic consumption of } \mathrm{j}}\right)}{\left.\sum_{\mathrm{j}} \text { (industry k purchases of good } \mathrm{j}\right)}
$$

The primary shortcoming of this measure is the use of good j's share of imports in total domestic consumption, in the numerator, which is computed for the entire U.S. economy. Obviously, it would be preferable to measure this share by just using data for purchasing industry $\mathrm{k}$, as we shall attempt to do in the second step of this project. As it is stated, (1) essentially assumes that the economy-wide import share for good $\mathrm{j}$ is the same as the industry $k$ import share for good $\mathrm{j}$, which is the "import comparability" assumption.

Given this limitation of (1), there are still some improvements that can be considered before using firm-level data. Specifically, we consider re-calculating the measure of offshoring 
in (1) while focusing more carefully on only imported intermediate inputs. Specifically, the inputs j that are used in (1) are defined by the classifications used in input-output tables of the United States: either 4-digit SIC before 1996 or 6-digit NAICS after 1996. For each of classifications, there will be multiple 10-digit Harmonized System (HS) imported products. Let us denote by $i \in I_{j}$ the set of 10-digit HS products within each 4-digit SIC before 1996 or 6-digit NAICS good i. Then a more accurate definition of the Feenstra and Hanson (1999) measure of materials offshoring is:

Industry k share of intermediate inputs that are imported

$$
=\frac{\left.\sum_{j} \text { (industry } k \text { purchases of good } \mathrm{j}\right)\left(\frac{\text { sum over imports } \mathrm{i} \in \mathrm{I}_{\mathrm{j}}}{\text { total domestic consumption } \mathrm{i} \in \mathrm{I}_{\mathrm{j}}}\right)}{\sum_{\mathrm{j}} \text { (industry } \mathrm{k} \text { purchases of good } \mathrm{j} \text { ) }}
$$

A problem with this definition of offshoring is that some of the imported products i can be final goods rather than intermediate inputs. Imports of such final goods are often not what we have in mind with materials offshoring. To correct this problem we can restrict attention to HS goods with corresponding "end-use codes" that are indeed intermediate inputs. The end-use codes are used by the Bureau of Economic Analysis to allocate goods to their final use, within the National Income and Product Accounts. Accordingly, U.S. imports and exports by Harmonized System are also allocated to end-use codes. As described by the Census Bureau, Guide to Foreign Trade Statistics: ${ }^{1}$

The 1-digit level end-use categories provide data for the following broad aggregates: (0)

Foods, feeds, and beverages ; (1) Industrial supplies and materials; (2) Capital goods,

\footnotetext{
${ }^{1}$ Slightly amended from: http://www.census.gov/foreign-trade/guide/sec2.html.
} 
except automotives; (3) Automotive vehicles, parts and engines; (4) Consumer goods (nonfood), except auto; and (5) Other merchandise.

...The HTSUSA and Schedule B classifications are summarized into six principal "enduse" categories and further subdivided into about 140 broad commodity groupings. These categories are used in developing seasonally adjusted and constant dollar totals. The concept of end-use demand was developed for balance of payments purposes by the Bureau of Economic Analysis.

Based on the numbering system defined in the above quotation, food and other items begin with the digit " 0 ", which include both final goods and intermediate inputs; raw materials and intermediate goods begin with “1”; investment goods begin with the digit "2"; automotive goods begin with "3", which include both final goods (finished autos) and intermediate inputs (parts); final consumer goods (nonfood) begin with the digit “4”; and “5” is a miscellaneous category. In the Appendix we list the precise 5-digit end-use codes that are included within final goods (i.e. consumption and investment), while all other end-use codes are treated here as intermediate inputs or raw materials. ${ }^{2}$

Using this end-use classification, we consider a restricted set of HS codes within each SIC or NAICS industry j:

$$
\overline{\mathrm{I}}_{\mathrm{j}} \equiv\{\text { HS goodsi within the industry } \mathrm{j} \text { that are also intermediate inputs }\} \text {. }
$$

Then the revised measure of materials offshoring is:

\footnotetext{
${ }^{2}$ We thank Marshall Reinsdorf, Bureau of Economic Analysis, for providing the end-use classifications in the Appendix. As noted in the Appendix, certain raw materials such as oil and minerals are always excluded from the offshoring calculation.
} 


$$
\frac{\sum_{j}(\text { industry k purchases of good } \mathrm{j})\left(\frac{\text { sum over imports } i \in \overline{\mathrm{I}}_{\mathrm{j}}}{\text { total domestic consumption } \mathrm{i} \in \overline{\mathrm{I}}_{\mathrm{j}}}\right)}{\sum_{\mathrm{j}} \text { (industry k purchases of good } \mathrm{j} \text { ) }} \text {. }
$$

Note that the import share used in the numerator of (2) restricts the set of goods used in both the numerator and the denominator, so we cannot tell how it compares with the import share used in (1'). Specifically, the denominator of this import share is constructed as:

$$
\begin{aligned}
& \text { total domestic consumption } i \in \overline{\mathrm{I}}_{\mathrm{j}} \\
& \text { = domesticshipments for } \mathrm{i} \in \overline{\mathrm{I}}_{\mathrm{j}}+\text { sum over imports } \mathrm{i} \in \overline{\mathrm{I}}_{\mathrm{j}}-\text { sum over exports } \mathrm{i} \in \overline{\mathrm{I}}_{\mathrm{j}} \text {. }
\end{aligned}
$$

The import and export terms in this expression do not need any explanation: they are simply the sum over HS imports or exports within the SIC or NAICS industry j, that are also intermediate inputs (as defined by their End-use classification). But the domestic shipments term does require an explanation. Rather than use the total domestic shipments of industry j, we instead apportioned those domestic shipments into various HS products i, by assuming that the share of domestic shipments for each HS product i within industry j equals the share of U.S. exports in that HS product and industry. We then sum domestic shipments over just those HS products that are also intermediate inputs (as defined by their end-use classification).

\section{Empirical Implementation}

We construct the offshoring measure (2) for all years between 1980 and 2006 within the manufacturing sector. We begin with measures of intermediates purchases by U.S. industries, which are obtained from the Economic Census for benchmark years (1982, 1987, 1992, 1997, 2002). Prior to 1997 values are by 4-digit SIC codes and post-1996 values are by 6-digit NAICS. 
Each observation in the Economic Census benchmark dataset contains a purchasing industry, a corresponding intermediate industry which provides inputs, and a total value of purchases (inputs). To obtain purchases for all years for an industry from a particular intermediate industry, we simply interpolate and extrapolate the benchmark values linearly throughout the period 1980 to $2006 .^{3}$

The next step is to construct the import share of intermediates in domestic consumption of intermediates. This industry share will be merged with the input-providing industries from the purchases data described above. First, we merge data on imports and exports from Feenstra (1996, 2002) with yearly data on total industry shipments, obtained from the Annual Survey of Manufactures. Again, prior to 1997 these data are by 4-digit SIC and post-1996 by 6-digit NAICS, so the merge is straightforward.

Now, in order to restrict the imports, exports, and shipments to intermediates only, we use the end-use categories which are matched to SIC and NAICS industries in the import/export datasets. The end-use categories that we excluded because they are "final goods" come from a list provided by the BEA, as shown in the Appendix. We separate out investment goods and most automobile categories from the list because these include many things that we think of as vulnerable to offshoring, such as automobile parts, machinery and equipment, and therefore we ultimately would like to include these items. For personal consumption expenditure (PCE) goods a portion of the list is more subjective, with some categories split between intermediate and final goods. Here we simply remove all end-use categories which encompass some final goods, and since the categories which are problematic are primarily food items, which we don't generally associate with offshoring activities, this approach seems reasonable. In addition, we remove

${ }^{3}$ The 2007 benchmark will be available beginning in June and we will be able to reduce error caused by the extrapolation of the 2002 benchmark. 
certain raw materials detailed in the Appendix, such as petroleum products and various metals, whose value and import volumes are likely unrelated to offshoring activities.

Table 1 shows trends in the offshoring measure using the original method of Feenstra and Hanson (19990, i.e. equations (1) or (1'). We report both a "broad” and a "narrow" offshoring measure as in Feenstra and Hanson (1996, 1999), where the "narrow" measure restricts the final and intermediate industries to be within the same 3-digit NAICS categories. In comparison, Table 2 details trends in the revised offshoring measure, equation (2), with and without inclusion of investment goods.

We have compared the original and revised offshoring measures, to determine which industries show the greatest differences (averaged over years), and obtain the results:

NAICS 339931: Dolls and Stuffed Toys, Difference $\approx 0.85$

NAICS 315991: Hats and Caps, Difference $\approx 0.35$

NAICS 331316: Aluminum Extruded Products, Difference $\approx 0.35$

NAICS 311320: Chocolate and Confectionary Products, Difference $\approx 0.29$

NAICS 339941: Pens and Mechanical Pencils, Difference $\approx 0.28$

NAICS 339992: Musical Instruments, Difference $\approx 0.25$

The industries with the greatest difference are simply consumer items that are imported directly to retail outlets, so these imports are clearly final goods, and therefore omitted from the revised offshoring measure. 


\section{Assigning Imported Inputs to Industries using Firm-level Data}

In this section, we explore an alternative methodology to the "import comparability assumption” for allocating imported inputs across industries. This alternative methodology uses transaction data on firms' imports linked to production data at the firm and plant level to construct something analogous to firm-level input-output tables and then aggregates the firmlevel input-output tables to produce an aggregate import matrix that allocates imported intermediate inputs (IO commodities) across industries. This approach offers promise in that it provides a different perspective on the allocation of imported intermediate inputs across industries. Our objective in the remainder of the paper is to explain the alternative methodology, describe some of the challenges we faced in trying to produce this, and then attempt to characterize (within the limits of disclosure) how our alternative import matrix differs from the import matrix provided by BEA.

\section{Data Used and Assignment Methodology}

We use information on imports from 1997 from the Linked/Longitudinal Firm Trade Transaction Database (LFTTD), which links individual U.S. trade transactions to firms. ${ }^{4}$ We use information on materials used and products produced from the 1997 Census of Manufactures. Because both datasets contain a firm-level identifier, it is possible to link imported inputs to production data (materials used and products produced) of the firms that import the intermediates. We will use this information to construct a firm-level input-output table that allocates imported inputs across the manufacturing industries in which the firm produces.

\footnotetext{
${ }^{4}$ See Bernard, Jensen, Schott (2009) for more details on the LFTTD.
} 
The first limitation we confront is that the LFTTD contains firm-level identifiers for 8085 percent of import value (roughly 10 percent of value is associated with transactions that have no Employer Identification Number). As a result, our estimates of total import value across commodities are systematically lower than BEA's and this difference varies across commodities. (When we compare our allocation of imports across industries to BEA's import matrix, we will compare the shares of imports by industry (instead of levels) between the two methodologies to try to mitigate the impact of this problem.)

The LFTTD contains information on products at the 10-digit Harmonized System (HS) classification level. We use publicly available concordances between 10-digit HS products and 6-digit BEA input-output (IO) commodities and assign 6-digit IO commodity codes to all firmlevel imports. We now have firm imports on an IO commodity basis.

The next step is to allocate the firm's imports to the industries that use the imports in production. Our intention was to use information collected in the Census of Manufactures regarding materials used by manufacturing establishments as a way of allocating the use of imported intermediate inputs to industries. The information on materials used is contained in “material trailers” in the Census of Manufactures files and is classified using internal Census Bureau material codes. To use this information to allocate imported commodities, we needed a bridge between internal Census Bureau materials codes and IO commodity codes. We obtained internal BEA concordances between Census material codes and BEA IO codes. ${ }^{5}$ Using these codes, we were able to allocate materials used to IO industries. ${ }^{6}$ The assignment of materials

\footnotetext{
${ }^{5}$ We thank Belinda Bonds of BEA for providing the internal version of the concordance.

${ }^{6}$ We used a concordance between NAICS industry classifications and BEA IO industry classifications.
} 
used to industries identified another limitation of our methodology - the value reported in the material trailers accounts for only about $75 \%$ of the total materials used in the BEA IO tables. ${ }^{7}$

Another complication we confronted in allocating imported inputs to industries is that the vast majority of trade value is mediated by large, multi-unit, multi-activity firms. ${ }^{8}$ Many of these firms have establishments classified in a range of sectors, e.g. the manufacturing sector, the wholesale sector, and the retail sector. Allocating imports across industries within these firms proved difficult. One source of the difficulty is that the materials used information is not collected in the same way for sectors outside of manufacturing, so we needed some way to allocate commodity imports across industries. We tried allocating based on the share of a firm's total sales each establishment accounted for, but found we were allocating significant value for “end use” commodities to manufacturing establishments owned by multi-sector firms. To mitigate this problem, we excluded from our analysis 10-digit HS products classified as “end use” by Wright (2009) and restricted our analysis to the manufacturing establishments of importing firms.

After excluding “end use” products and non-manufacturing establishments/firms, we were able to allocate 50 percent of total imported intermediate input value to manufacturing establishments using the material codes (i.e. imported intermediate inputs were assigned to an establishment's IO industry if the establishment reported using the material); the remainder of imported intermediate value was allocated based on establishments' share of a firm’s manufacturing output. Because we exclude establishments within a firm that are outside of

\footnotetext{
${ }^{7}$ BEA uses other sources and methodologies for constructing the materials used in the IO tables. Conversations with BEA staff suggested that our finding that the material trailers accounted for 75 percent of the IO value was in the right ballpark. There is a high correlation across commodity-industry cells between our materials used values and the BEA IO tables materials used.

${ }^{8}$ See Bernard, Jensen, and Schott (2009).
} 
manufacturing, it is possible that we over-allocate imports to firms that have both manufacturing operations and import for wholesale or retail operations. This highlights another potential compromise in our methodology - that a significant share of imported intermediate value is imported by firms whose manufacturing establishments do not report using the material. ${ }^{9}$

With the assignment of imported intermediate inputs (IO commodities) to establishments that are classified by industry (IO industry), we have essentially created firm level input-output tables with IO commodity by IO industry cells. The final step is to aggregate these firm-level cells to obtain an import matrix for the manufacturing sector.

\section{Comparison of BEA's Import Matrix to our Alternative Import Matrix}

In this section, we attempt to characterize whether the allocation of imported intermediate inputs differs between BEA's import matrix, which uses the import comparability assumption, and our alternative matrix, which uses firm-level data to assign commodities to industries - and, if so, where it differs. ${ }^{10}$ Assessing whether the matrices differ in a meaningful way is obviously a bit subjective and would depend to some extent on the purpose for which the matrix would be used. We present descriptive statistics that attempt to quantify and characterize the differences between the matrices from the two methodologies.

We focus on the share of a commodity's import value assigned to a particular industry instead of the level of import value to mitigate the issue posed by the systematic under-allocation of imported inputs in our data. To make the comparison, we consider only agricultural and

\footnotetext{
${ }^{9}$ It is difficult to know how to interpret this fact. One possibility is a reporting issue, i.e. establishments either under-report the materials that they use or report only in the "materials not elsewhere classified" code. An alternative explanation is that firms import a significant share of intermediate inputs that they do not use for production.

${ }^{10}$ Characterizing the differences at a detailed level is difficult because of the constraint of confidentiality.
} 
manufactured commodities and only manufacturing industries in BEA's import matrix (the same commodities and industries we included in the alternative methodology). ${ }^{11}$ For the manufacturing sector, we calculate the share of an IO commodity's total imports that is allocated to each IO industry within manufacturing. We calculate the share of an IO commodity's total imports that we allocate to each IO industry within manufacturing. We compare the shares in these IO-commodity IO-industry cells.

We begin by examining the simple correlation between the share of each 3-digit commodity group’s total import value assigned to a 3-digit IO-industry cell in the two matrices. The simple correlation and BEA-value-weighted correlation are reported in Table 3. There is a high correlation between the share in both the simple correlation and the weighted correlation; the correlation is actually higher for the value-weighted correlation.

We also examine the distribution of the differences between the shares in the two matrices at the 3-digit IO commodity/IO industry cell level. Figure 1 exhibits the distribution of share differences for 3-digit cells. Most of the cells have very small differences in the share of the imported intermediate input (IO commodity) across industries. This suggests that for most cells, the share of the commodity imports allocated to a particular industry is fairly close in many cells. The high correspondence may be due to the large number of cells for which both methods allocate zero imports.

We also examine the BEA import-value-weighted distribution of share differences to see whether we match the allocated shares as closely for IO commodity/IO-industry cells with relatively large import values. Figure 2 shows the BEA-import-value-weighted distribution. The value-weighted distribution is obviously more dispersed. For IO-commodity/IO-industry cells

\footnotetext{
${ }^{11}$ This excludes IO-commodities that BEA allocates to IO-industries outside of manufacturing. IOindustries outside of manufacturing can account for a significant share of value of some IO-commodities.
} 
with relatively high import values, the import matrices derived from the "import comparability assumption" method and our alternative method are more different. In contrast to the unweighted distribution, significantly less mass is at zero or small share differences. While most valueweighted cells have differences below 50 percentage points, there is significant mass of the distribution that differs by 10 percentage points or more.

We also thought it would be useful to show the IO-commodity IO-industry cells where the two methodologies have the largest share differences. We were constrained a bit by the disclosure prevention protocols, but were able to release 15 cells from the 10 largest positive and 10 largest negative differences. The cells are listed in Table 4.

The results highlight some of the limitations and conceptual differences inherent in our alternative approach. For example, the IO-commodity IO-industry cell in the first row of the top panel of Table 4 shows that our methodology allocated a significant share of IO-commodity 337 Furniture imports to IO-industry 337 Furniture. BEA had a much smaller share of furniture imports allocated to this IO-industry. The first row of the negative panel shows that BEA allocated a large share of furniture imports to IO-industry 321 Wood Products. In fact, BEA allocated very little in terms of import value to IO-industry wood products, but instead allocated most of the value of furniture imports outside of the manufacturing sector. Our allocation methodology allocated furniture imports by furniture manufactures to IO-industry 337 Furniture. BEA allocated the furniture imports to the Construction sector. It would require additional research, and in the end it might be infeasible, to determine whether the furniture importers that are furniture manufactures are adding value to the furniture imports or are merely acting as wholesalers. Yet, to determine which allocation method is more appropriate would require this type of investigation. 
The 3-digit IO-commodity IO-industry cells are a bit unsatisfactory because of the relatively high level of aggregation (but are necessitated by the disclosure prevention protocols). To provide some sense of how the matrices compare at a more detailed level, we report descriptive statistics for weighted and unweighted share differences at the 6-digit IO-commodity IO-industry level. Table 5 reports the mean share difference (weighted and unweighted) for the IO-commodity IO-industry cells in the 90 to $100^{\text {th }}$ percentile and the 0 to $10^{\text {th }}$ percentile. The unweighted share differences are relatively small - only about 2 percentage points - at both the high end and the low end. The BEA-import-value-weighted means tell a somewhat different story. The weighted-average at the low end is more than 50 percentage points different. There are some 6-digit cells with relatively large import values where BEA allocates significantly more import value to the industry than the alternative measure does. At the other end of the distribution, the differences are smaller, about 16 percentage points different. While it would be desirable to provide more information on the share differences at a very detailed level, fortunately the aggregation to the 3-digit level does not seem to distort the overall story much.

In summary, this alternative methodology seems to offer promise and probably warrants additional investigation. The comparison of the import matrices derived from the alternative methodology to BEA's matrix highlight some of the data limitations confronted by the firm-level methodology and possibly point out some conceptual differences between the two methodologies. To resolve which allocation is more appropriate would require additional information. As such, the exercise points out some potential short-comings in current data collection systems - of particular interest is additional work to resolve the issue of firms importing intermediate inputs that are not reported as being used in production. 


\section{Conclusion}

In the first part of this paper, we explored alternatives to the Feenstra-Hanson (1999) measure of offshoring that still make use of the import comparability assumption. While that measure of offshoring was intended to reflect imported intermediate inputs, in practice it also included imported final goods. So in this first step, we re-calculated the Feenstra-Hanson (1999) measure of offshoring while focusing on only imported intermediate inputs as defined by enduse classifications.

In the second step, we explored a different methodology for allocating imported inputs across industries using firm level data on imports and production. We used linked production and import data to construct firm-level input-output tables and then aggregate these to the industry level to derive imported input intensity by industry. We compared the results of this alternative allocation methodology with those obtained by the BEA using the "import comparability" assumption. The comparison of the import matrices derived from the alternative methodology to BEA's matrix highlight some of the data limitations confronted by the firm-level methodology and possibly point out some conceptual differences between the two methodologies. 


\section{Appendix: End-Use Final Goods}

\section{Personal Consumption Expenditure:}

The following include both final and intermediate goods:

00020 Cane and beet sugar

00100 Meat products \& poultry

00110 Dairy products \& poultry

00120 Fruits \& preparations including juices

00130 Vegetables \& preparations

00140 Nuts \& preparations

00150 Food oils \& oilseeds

00160 Bakery products \& confectionery

00170 Tea, spices, \& preparations

00180 Agricultural foods, n.e.c.

00190 Wine \& related products

01000 Fish and shellfish

01010 Whiskey and other alcoholic beverages

01020 Other nonagricultural foods \& food additives

15200 Fabricated metal products

16110 Blank audio and visual tapes and other media

The following are final goods only:

40000 Apparel, \& household goods--cotton

40010 Apparel, \& household goods--wool

40020 Apparel, \& household goods--other textiles

40030 Non-textile apparel \& household goods

40040 Footwear of leather, rubber \& other materials

40050 Sporting \& camping apparel, footwear \& gear

40100 Medicinal, dental, \& pharmaceutical preparations includ. vitamins

40110 Books, magazines, \& other printed matter

40120 Toiletries \& cosmetics

40140 Consumer nondurables, n.e.c.

41000 Furniture, household items \& baskets

41010 Glassware, porcelain, \& chinaware

41020 Cookware, cutlery, house \& garden ware \& tools

41030 Household and kitchen appliances

41040 Rugs \& other textile floor coverings

41050 Other household goods

41100 Motorcycles \& parts

41110 Pleasure boats \& motors

41120 Toys, shooting \& sporting goods, including bicycles

41130 Photographic \& optical equipment

41140 Musical instruments \& other recreational equipment

41200 Television receivers, video receivers, \& other video equipment

41210 Radios, phonographs, tape decks, \& other stereo equipment \& parts

41220 Records, tapes, \& disks

413 Coins, gems, jewelry, \& collectibles 
42000 Unmanufactured goods

421 Unmanufactured diamonds

Investment (final goods):

20000 Generators, transformers, and accessories

20005 Electrical equipment and parts n.e.c.

21000 Oil-drilling, mining, and construction machinery

21100 Industrial engines, pumps, compressors, and generators

21110 Food- and tobacco-processing machinery

21120 Machine tools \& metal-working machinery, molding and rolling

21130 Textile, sewing and leather working machinery

21140 Woodworking, glass-working \& plastic- and rubber-molding mach.

21150 Pulp \& paper machinery, bookbinding, printing \& packaging mach.

21160 Measuring, testing, and control instruments

21170 Materials-handling equipment

21180 Other industrial machinery

21190 Photo- \& service-industry machinery and trade tools

21200 Agricultural machinery and equipment

21400 Telecommunications equipment

21500 Other business machines

21600 Scientific, hospital, and medical equipment and parts

22000 Civilian aircraft, complete*

22010 Civilian aircraft, parts

22020 Civilian aircraft, engines

22100 Railway \& other commercial transportation equipment

22200 Vessels (except military \& pleasure craft) \& misc. vehicles

22300 Spacecraft, engines \& parts, except military

Automotive Vehicles, Parts, and Engines (final and intermediate goods):**

30000 Passenger Cars, New and Used

30100 Complete and Assembled

Raw Materials (not final goods nor intermediate inputs):*

14200 Bauxite and Aluminum

14220 Copper

14240 Nickel

14250 Tin

14260 Zinc

14270 Nonmonetary Gold

14280 Other Precious Metals

14290 Misc. Non-ferrous Metals

10 Crude, Fuel Oil, Other Petroleum products, Coal, Gas, Nuclear Fuel, Electric Energy

* These classifications are always excluded from the offshoring calculation.

** This broad category include both final and intermediate goods. Those listed here are final goods and are excluded from the offshoring calculation. 


\section{References:}

Bergstrand, Jeffrey H. and Peter Egger, 2008, "Finding Vertical Multinational Enterprises,” University of Notre Dame, University of Munich and CESifo, February.

Feenstra, Robert C., 1996, “U.S. Imports, 1972-1994: Data and Concordances,” NBER Working Paper no. 5515.

Feenstra, Robert C. and Gordon H. Hanson, 1999, “The Impact of Outsourcing and HighTechnology Capital on Wages: Estimates for the U.S., 1979-1990,” Quarterly Journal of Economics, August, 114(3), 907-940.

Feenstra, Robert C., John Romalis and Peter Schott, 2002“U.S. Imports, Exports and Tariff Data, 1989-2001,” NBER Working Paper no. 9387.

Houseman, Susan N., 2008, Outsourcing and Offshoring: Problems for Price and Productivity Measurement,” Upjohn Institute for Employment Research, June.

National Research Council, 2006, “Analyzing the U.S. Content of U.S. Imports and the Foreign Content of U.S. Exports.”

Sitchinava, Nino, 2007, “Market Structure Index of HTS Imports,” University of Oregon.

Sitchinava, Nino, 2008, “Trade, Technology, and Wage Inequality: Evidence from U.S. Manufacturing, 1989-2004,” University of Oregon, Ph.D. dissertation.

Winkler, Deborah and William Milberg, 2009, “Errors from the "Proportionality Assumption” in the Measurement of Offshoring: Application to German Labor Demand,” Schwartz Center for Economic Policy Analysis and Department of Economics, New School for Social Research, New York, SCEPA Working Paper 2009-12.

Wright, Greg C., 2009, “Task-Specific Offshoring Costs: Measurement Across Countries and Over Time”, University of California, Davis, Ph.D. dissertation. 
Table 1

Offshoring Trends with original Feenstra-Hanson calculation (equation 1)

\begin{tabular}{|c|c|c|c|}
\hline Year & $\begin{array}{c}\text { Narrow } \\
\text { Measure }\end{array}$ & Broad Measure & $\begin{array}{c}\text { Broad minus } \\
\text { Narrow Measure }\end{array}$ \\
\hline 1980 & 0.047 & 0.071 & 0.024 \\
1990 & 0.067 & 0.123 & 0.055 \\
2000 & 0.103 & 0.228 & 0.124 \\
2006 & 0.129 & 0.282 & 0.152 \\
\hline
\end{tabular}

Table 2

Revised Offshoring Trends (equation 2)

\begin{tabular}{|c|cc|cc|}
\hline & \multicolumn{2}{|c|}{ With Investment Goods Included } & \multicolumn{2}{|c|}{ Without Investment Goods } \\
\hline Year & Narrow Measure & Broad Measure & Narrow Measure & Broad Measure \\
\hline 1980 & 0.032 & 0.066 & 0.032 & 0.065 \\
1990 & 0.054 & 0.121 & 0.049 & 0.122 \\
2000 & 0.091 & 0.197 & 0.083 & 0.204 \\
2006 & 0.119 & 0.270 & 0.105 & 0.274 \\
\hline
\end{tabular}


Table 3

\section{Correlation between Import Value Share across 3-digit IO-Commodity IO-Industry Cells}

Unweighted

Table 4

\begin{tabular}{|c|c|c|c|c|}
\hline \multicolumn{5}{|c|}{10 Commodity 10 Industry Cells with Largest Share Differences } \\
\hline 3-digit IO Commodity Group & 3-digit IO Industry Group & Alt. Share & BEA Share & Share Difference \\
\hline 337 Furniture and Related Products & 337 Furniture and Related Products & 0.50 & 0.01 & 0.50 \\
\hline 324 Petroleum and Coal Products & 324 Petroleum and Coal Products & 0.82 & 0.34 & 0.48 \\
\hline 315 Apparel & 316 Leather and Allied Products & 0.46 & 0.00 & 0.46 \\
\hline 326 Plastics and Rubber Products & 326 Plastics and Rubber Products & 0.56 & 0.18 & 0.38 \\
\hline 323 Printing and Related Support Activities & 334 Computer and Electronic Products & 0.38 & 0.01 & 0.37 \\
\hline 316 Leather and Allied Products & 316 Leather and Allied Products & 0.61 & 0.26 & 0.35 \\
\hline 325 Chemicals & 325 Chemicals & 0.73 & 0.46 & 0.28 \\
\hline 335 Electrical Equipment and Components & 335 Electrical Equipment and Components & 0.40 & 0.20 & 0.20 \\
\hline 3-digit IO Commodity Group & 3-digit IO Industry Group & Alt. Share & BEA Share & Share Difference \\
\hline 337 Furniture and Related Products & 321 Wood Products & 0.06 & 0.98 & -0.92 \\
\hline 114 Fishing, Hunting, and Trapping & 311 Food & 0.18 & 1.00 & -0.82 \\
\hline 323 Printing and Related Support Activities & 323 Printing and Related Support Activities & 0.12 & 0.73 & -0.62 \\
\hline 311 Food & 312 Beverage and Tobacco Products & 0.00 & 0.36 & -0.36 \\
\hline 324 Petroleum and Coal Products & 325 Chemicals & 0.13 & 0.46 & -0.32 \\
\hline 316 Leather and Allied Products & 314 Textile Products & 0.00 & 0.22 & -0.22 \\
\hline 316 Leather and Allied Products & 323 Printing and Related Support Activities & 0.00 & 0.22 & -0.22 \\
\hline
\end{tabular}

\section{Table 5}

Mean Differences in Shares for 6-digit level IO-Commodity IO_Industry Cells

\begin{tabular}{|lrr|}
\hline & 0 to 10th Percentile & 90 to 100th Percentile \\
Unweighted & -0.021 & 0.020 \\
Weighted (by BEA import value) & -0.543 & 0.165 \\
\hline
\end{tabular}


Figure 1

Histogram of Difference in Commodity-Industry Cell Import Share

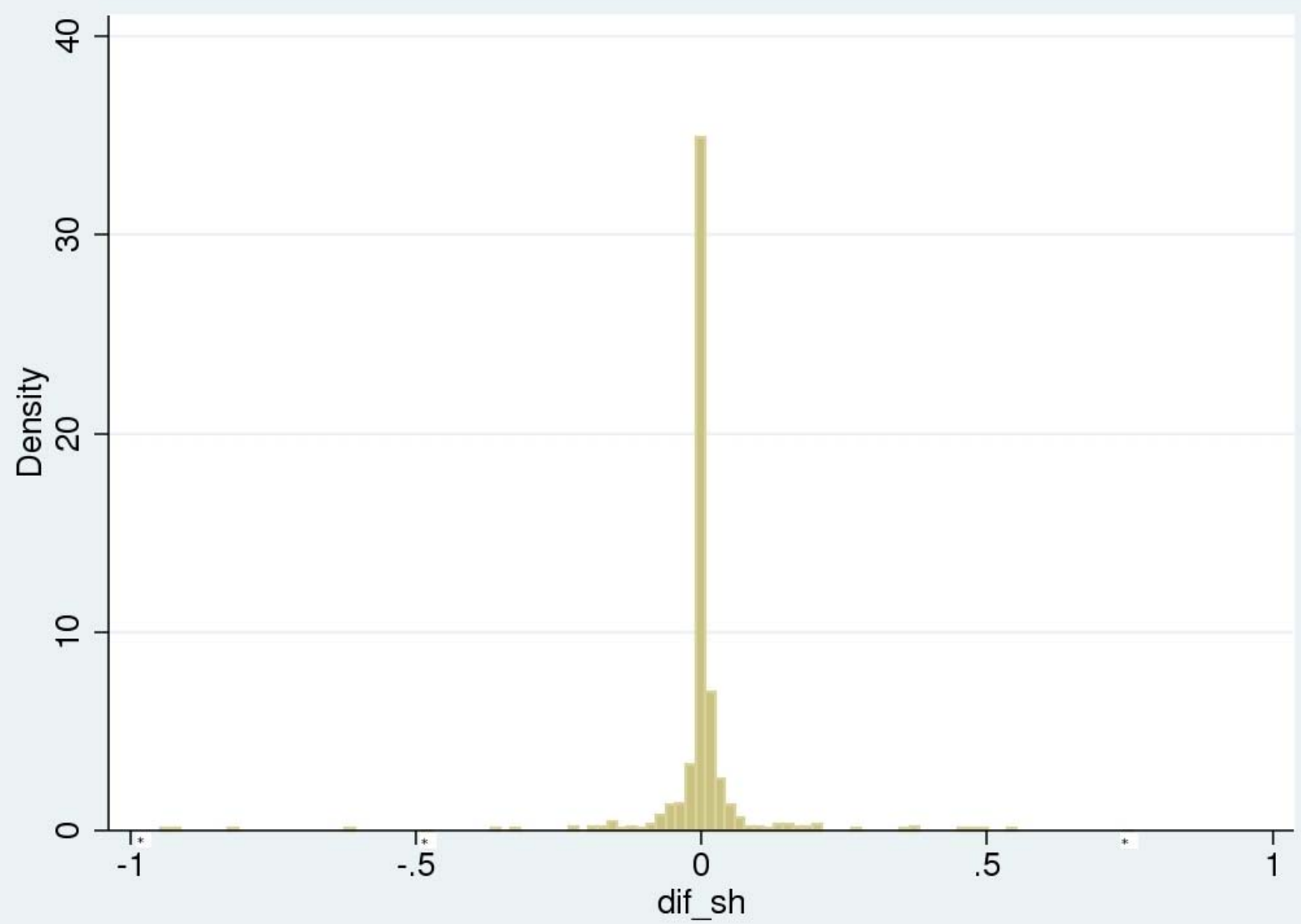


Figure 2

Histogram of Difference in Commodity-Industry Cell Import Share (Weighted by BEA Import Value)

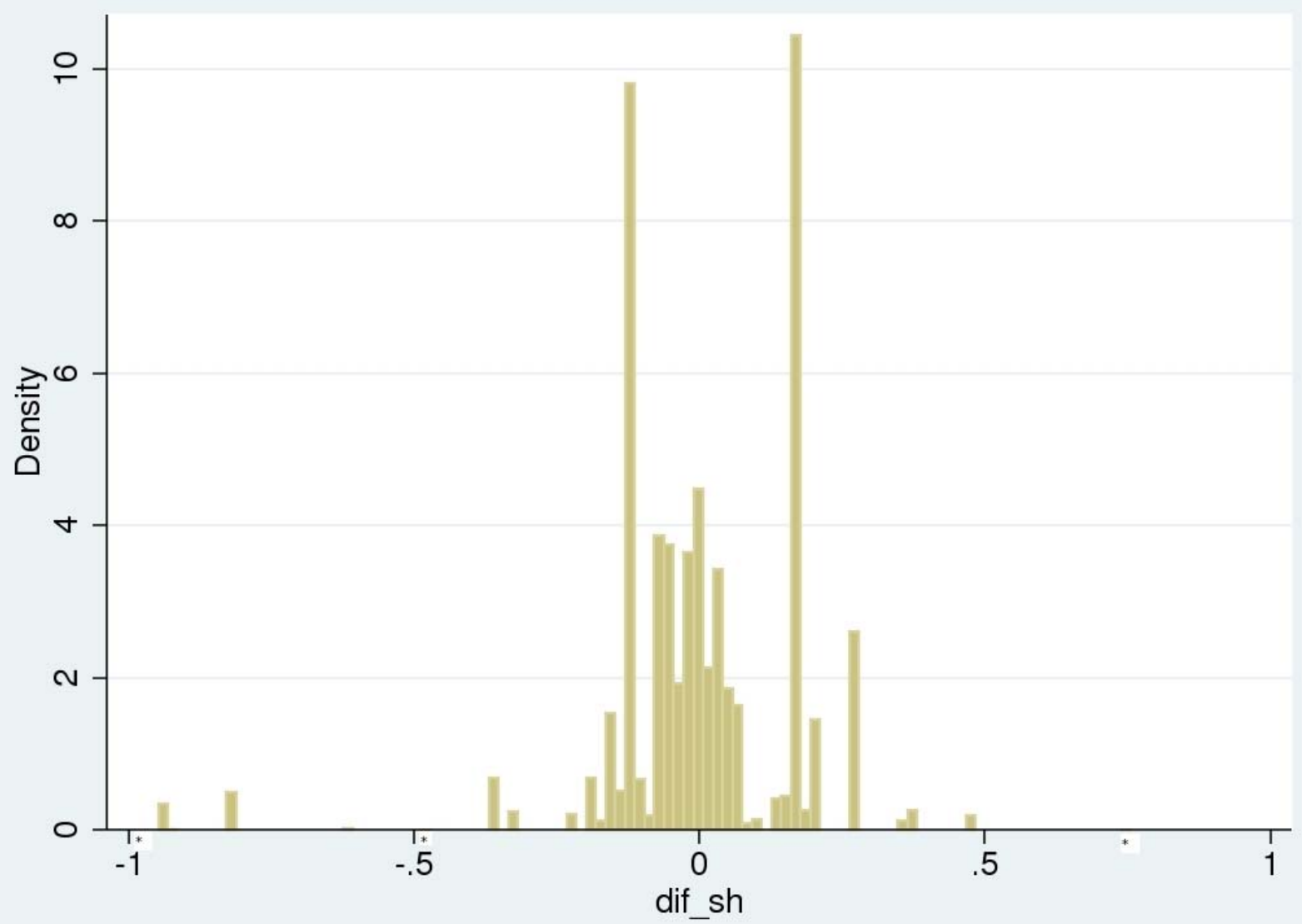

